\title{
Kebijakan dan implementasi program pelatihan kejuruan bagi anak jalanan di Kabupaten Subang
}

\author{
Tera Ummuttaufiqoh ${ }^{1}$, Hendi Suhendraya Muchtar ${ }^{1}$ \& Supyan Sauri
}

\begin{abstract}
The increasing number of street children in Subang Regency became a social problem that it raised questions about the government's role in handling street children. The purpose of this research was to examine the policy and implementation of the Subang Regency Social Services program in fostering street children through vocational training, as well as to examine the problems of implementing vocational training, and what attempts were made to overcome these problems. The theory of constructivism supported this research because it was expected that street children would be able independently to form the knowledge that has been previously acquired and then combined it with the new knowledge gained in vocational training. This research procedure used a qualitative descriptive method in the form of case study research. The results of the research on program policies and the implementation of vocational training for street children were not carried out directly at the Social Services, due to several problems, including limited budgets, Regional Regulations have not been published yet and inadequate infrastructure, so that it needed an attempt to overcome the problems that was collaboration with Ministry of Social Affairs that was PPSBR institution (Panti Pemberdayaan Sosial Bina Remaja) which is located in several cities/districts. In conclusion, the policy of the Subang Regency Social Services program is not capable to realize coaching optimally through vocational training for street children.
\end{abstract}

\section{Keywords}

Implementation, policy, street children, vocational raining

\section{Pendahuluan}

Negara Indonesia merupakan negara yang besar dengan jumlah wilayah luas serta jumlah penduduk sekitar 260 juta yang memiliki berbagai jenis permasalahan diantaranya permasalahan anak jalanan. Pembangunan yang sedang kita laksanakan merupakan perwujudan dari tujuan negara yang tercantum dalam UUD 1945 alinea keempat yang berbunyi "Melindungi segenap bangsa Indonesia dan seluruh tumpah darah Indonesia dan untuk memajukan kesejahteraan umum, mencerdaskan kehidupan bangsa, dan ikut melaksanakan ketertiban dunia yang berdasarkan kemerdekaan, perdamaian abadi dan keadilan sosial".

Hal tersebut dijabarkan dalam setiap program pembangunan bidang pendidikan dan kesejahteraan nasional bagi seluruh anak yang ada di wilayah Republik Indonesia. Kesejahteraan anak ialah suatu tata kehidupan dan penghidupan sosial material maupun spritual yang diliputi oleh rasa keselamatan, kesusilaan dan ketenteraman lahir batin yang memungkinkan bagi setiap warganegara untuk mengadakan usaha pemenuhan kebutuhan-kebutuhan jasmaniah, rohaniah dan sosial yang sebaik-baiknya bagi diri, keluarga serta masyarakat dengan menjunjung tinggi hak asasi serta kewajiban manusia sesuai dengan Pancasila.
Peran pendidikan sebagai tonggak keberhasilan bangsa haruslah menjadi perhatian berbagai pihak. Pendidikan bukan hanya menjadi kewajiban orang tua, maupun Dinas Pendidikan, namun menjadi tanggung jawab bersama setiap warga Negara. Akan tetapi realitasnya, pendidikan di Indonesia yang terus berbenah tampaknya belum bisa menyentuh semua elemen masyarakat, khususnya anakanak jalanan. Maka sewajarnya, bagi kalangan anak jalanan yang sama sekali tidak pernah mencicipi dunia pendidikan, sikap dan perilakunya terkadang menyimpang dari norma-norma yang ada.

Pemerintah sangat berperan penting dalam mengantisipasi timbulnya permasalahan anak seperti anak jalanan, sehingga perlu adanya landasan hukum dalam penanganannya melalui Undang-undang Republik Indonesia Nomor 35 Tahun 2014 Perlindungan Anak (2014) yang menyatakan bahwa "Setiap anak berhak memperoleh

\footnotetext{
${ }^{1}$ Universitas Islam Nusantara

Korespondensi:

Tera Ummuttaufiqoh, Pascasarjana Program Studi Administrasi Pendidikan, Universitas Islam Nusantara

Email: tera.uthe@gmail.com, hendipnf@gmail.com, uyunsufyan@yahoo.coid
} 
pendidikan dan pengajaran dalam rangka pengembangan pribadinya dan tingkat kecerdasannya sesuai dengan minat dan bakat". Pendidikan bukan hanya pemenuhan akan pelajaran umum, namun pendidikan merupakan pemenuhan keseluruhan kebutuhan baik jasmani maupun rohani, sehingga menghasilkan SDM yang berkualitas. Kebijakan atau program sebuah lembaga haruslah diimplementasikan, dimana hal tersebut tentunya memiliki berbagai tahapan yang harus dilaksanakan.

Hasil data dari Badan Pusat Statistik (BPS) Jawa Barat di Kabupaten Subang, pada tahun 2016 terdapat anak terlantar (anak jalanan dan gelandangan) sebanyak 81 anak, pada tahun 2017 sebanyak 53 anak, dan pada tahun 2018 sebanyak 53 anak. Hal ini menggambarkan bahwa ternyata jumlah anak terlantar (anak jalanan dan gelandangan) tetap yang kemudian harus menjadi perhatian lebih bagi pemerintah walaupun pada tahun 2017 menurun. Namun tidak cukup sampai disini masih banyak yang harus dilakukan agar jumlah anak jalanan tidak meningkat justru semakin tahun harus menurun. Data tersebut diperkuat dengan dokumen kerja yang terdapat pada bagian Rehabilitasi Sosial, Dinas Sosial Kabupaten Subang, sebagai tabel1.

Permasalahan yang dihadapi dalam penelitian ini berawal dari kenyataan semakin bertambahnya jumlah anak jalanan di Kabupaten Subang yang seharusnya mengenyam pendidikan yang layak pada seusianya. Berdasarkan kondisi tersebut, perlu disikapi agar anak jalanan hidup layak sebagaimana mestinya kehidupan normal bagi masa kanak-kanak, sehingga sangat perlu untuk pembinaan anak jalanan tersebut.

\section{Tujuan Penelitian}

Tujuan penelitian ini untuk memperoleh gambaran dan informasi tentang: (1) Kebijakan program kerja Dinas Sosial Kabupaten Subang dalam pembinaan anak jalanan melalui pelatihan kejuruan. (2) Implementasi program kerja Dinas Sosial Kabupaten Subang dalam pembinaan anak jalanan melalui pelatihan kejuruan. (3) Masalah-masalah yang dihadapi oleh Dinas Sosial dalam implementasi pembinaan anak jalanan di Kabupaten Subang. (4) Upaya perbaikan masalah implementasi kebijakan program Dinas Sosial Kabupaten Subang dalam pembinaan anak jalanan melalui pelatihan kejuruan.

Penelitian sebelumnya menggunakan metode penelitian kuantitatif sedangkan penulis menggunakan metode penelitian kualitatif. Penelitian sebelumnya berusaha menampilkan bagaimana kinerja Dinas Sosial dalam membina anak jalanan dengan sarana dan prasarana sedangkan penulis berusaha menampilkan bagaimana Dinas Sosial dalam pembinaan anak jalanan dengan pelatihan kejuruan.

\section{Teori Kontruktivisme}

Banyak pandangan dan pendapat tentang belajar dan pembelajaran. Secara umum belajar dapat dipandang sebagai proses memperoleh pengetahuan dan keterampilan untuk melakukan suatu tugas atau pekerjaan. Sedangkan pembelajaran merupakan proses interaksi satu sama lain antar komponen dalam sistem pembelajaran, yaitu pendidik, peserta didik, materi, tujuan dan metode yang digunakan. Pelatihan merupakan proses pembelajaran yang dilakukan dalam waktu relatif singkat. Maka, sangat erat hubungannya pembelajaran dalam suatu pelatihan, sehingga dalam penelitian ini digunakan teori kontruktivisme yang mana "Proses pembelajaran diawali dengan konflik kognitif, yang pada akhirnya pengetahuan akan dibangun sendiri oleh peserta didik melalui pengalaman dan hasil interaksi dengan lingkungannya" (Karli \& Margaretha, 2002).

Melalui pelatihan kejuruan, kegiatan pembelajaran bagi anak jalanan akan berlangsung secara efektif, selain waktu yang relatif singkat anak jalanan dihadapkan langsung dengan objek yang sedang dipelajari, hal ini akan mampu membangun pengetahuan baru dan pemahaman yang baik terhadap yang dipelajari. Sehingga teori kontruktivisme ini sangat erat hubungannya dengan pelaksanaan pelatihan kejuruan. Teori kontruktivisme selain digunakan sebagai acuan dalam pelaksanaan pelatihan kejuruan, teori ini pun sesuai dengan kebijakan yang telah dilakukan Dinas Sosial dalam pembinaan anak jalanan.

Konstruktivisme ini, sebuah kebijakan pada dasarnya merupakan hubungan intersubjektif (antar subjek dan lingkungan) untuk menemukan jalan terbaik dalam memecahkan masalah. Epistemologi konstruktivisme berdasar pada petunjuk bahwa pengetahuan adalah produk konstruksi manusia. Sebuah kebijakan, tidak sekedar mengacu pada nalar idealisme atau rasionalisme seseorang, atau kepentingan sesaat seseorang, melainkan hasil interaktif antara subjek dan lingkungannya, itulah yang disebut konstruktivisme.

\section{Teori Implementasi Kebijakan}

Terdapat cukup banyak model atau teori kritis mengenai implementasi kebijakan, penulis memanfaatkan pandangan yang dikemukakan oleh Handoyo (2012), yang menyebutkan ada tiga model implementasi kebijakan, yaitu model pendekatan top-down, bottom-up dan hybrid. Berikut ketiga model implemenetasi kebijakan ini, diharapkan dapat menjadi alat dalam mencapai tujuan penelitian ini: (1) Model atas-bawah (top-down), disebut juga 'policy centered', karena lebih memfokuskan pada upaya penerapan implementasi kebijakan. Bahasa lain, Handoyo (2012) mengatakan tujuan inti pendekatan top-down yakni mengidentifikasi penyebab masalah dalam implementasi kebijakan dalam mencapai tujuan kebijakan. (2) Model pertumbuhan dari bawah (bottom-up). Model ini, tidak memberikan kepuasan kepada sekelompok orang. Pendekatan ini, dianggap kurang realistis dalam menganalisis proses implementasi kebijakan. Pendekatan bottomup ini, memiliki keunggulan, yaitu mampu mendekatkan antara formulator (birokrat) dari akar rumput. Model ini pula, kesenjangan harapan dan cita antara perumus kebijakan dan akar rumput dapat diminimalisir. (3) Model 
Tabel 1. Data Anak Jalanan 2016 - 2018

\begin{tabular}{lccccc}
\hline \multirow{2}{*}{ No } & \multirow{2}{*}{ Kode } & Indikator Kinerja & \multicolumn{3}{c}{ Jumlah PMKS yang ditangani } \\
\cline { 4 - 6 } & & & 2016 & 2017 & 2018 \\
\hline 1 & 2 & 3 & 7 & 8 & 9 \\
1 & F1 & Anak Balita Terlantar & 0 & 0 & 1 \\
2 & F3 & Anak Yang Berhadapan Dengan Hukum & 64 & 11 & 11 \\
3 & F4 & Anak Jalanan & 0 & 14 & 26 \\
4 & F5 & Anak Dengan Kedisabilitas (ADK) & 0 & 0 & 0 \\
\hline
\end{tabular}

Hybrid (gabungan), pada kenyatannya, kedua pendekatan ini ternyata tidak mampu menyelesaikan masalah. Menurut Fischer et al. (2007), analisis bottom-up juga masih menyisakan masalah karena pada dasarnya, visi dan misi dari sebuah kebijakan, tidak selamanya dipahami oleh akar rumput. Istilah lain, akar rumput kadang tidak selamanya mampu memahami visi dan misi dari si perumus kebijakan oleh karena itu, pendekatan yang tepat itu, bukanlah memisahkan antara bottom-up dengan top-down, melainkan mengawinkan antara keduanya, yaitu ke dalam model hybrid. Model ini berupaya untuk memanfaatkan sisi positif dari model top-down dan juga bottom-up untuk memaksimalkan upaya pencapaian tujuan.

\section{Program Dinas Sosial}

Pembinaan terhadap anak jalanan ini dimaksudkan untuk meningkatkan kemampuan intelektual, kecakapan, keterampilan sehingga membentuk inisiatif, kreatif, kompeten, inovatif untuk mengantarkan mereka kepada kemandirian. Dalam pembinaan tersebut Dinas Sosial sebagai mediator memberikan kegiatan pemberdayaan guna membangkitkan kembali rasa percaya diri, agar dapat aktif dalam kehidupan sosial, serta terciptanya kesejahteraan sosial.

Program Dinas Sosial dalam pembinaan anak jalanan bertujuan memberikan perlindungan terhadap anak yang memerlukan perlindungan khusus, dan yang mengalami masalah sosial atau yang rentan terkena masalah sosial. Maka, melalui program pembinaan tersebut diharapkan masalah anak jalanan dapat dituntaskan. Pola pembinaan anak jalanan melalui Dinas Sosial, sebagai berikut: (1) Pembinaan keterampilan (skills). (2) Pembinaan yang melibatkan sejumlah tokoh masyarakat. (3) Pembinaan dengan pihak kepolisian. (4) Program pendidikan.

\section{Pelatihan}

Pelatihan adalah proses pembelajaran yang lebih menekankan pada praktek daripada teori yang dilakukan perorangan atau banyak untuk membantu meningkatkan kemampuan dalam satu atau berbagai keterampilan. Pelatihan sebagai upaya meningkatkan pengetahuan, mengubah sikap dan prilaku, serta mengembangkan keterampilan. Pelatihan merupakan salah satu usaha dalam meningkatkan mutu sumber daya manusia. Peserta perlu mengikuti pelatihan karena adanya tuntutan peningkatan keterampilan yang dapat disesuaikan dengan perubahan lingkungan kerja, strategi, dan lain sebagainya. Beberapa manfaat yang dapat diperoleh dengan adanya pendidikan dan latihan, diantaranya: (1) Membantu individu untuk dapat memecahkan masalah secara lebih baik. (2) Internalisasi dan operasionalisasi motivasi kerja, prestasi, tanggung jawab, dan kemajuan. (3) Mempertinggi rasa percaya diri dan pengembangan diri. (4) Membantu untuk mengurangi rasa takut, siap dengan tugas baru.

Dari penjelasan di atas, dapat dikatakan bahwa pelatihan merupakan bagian pendidikan yang mengandung proses belajar, untuk meningkatkan keterampilan di luar sistem pendidikan yang berlaku dan dilakukan dalam waktu relatif singkat dengan metodenya mengutamakan praktek daripada teori.

\section{Pelatihan Kejuruan}

Telah dibahas sebelumnya bahwa pelatihan merupakan upaya meningkatkan pengetahuan, mengubah sikap dan prilaku, serta mengembangkan keterampilan. Pelatihan merupakan bagian dari pendidikan yang menyangkut proses belajar, berguna untuk memperoleh dan meningkatkan keterampilan di luar sistem pendidikan yang berlaku, dalam waktu relatif singkat dan metodenya mengutamakan praktek dari pada teori.

Dalam penggunaan teori pelatihan kejuruan, penulis mengadopsi dari beberapa pengertian pendidikan kejuruan. Pendidikan kejuruan yang ada merupakan tempat belajar formal yang justru dihindari oleh anak jalanan. Berangkat dari hal tersebut, penulis mengambil kata pelatihan kejuruan (walaupun hakikatnya sama). Maka, apabila ditinjau secara sistem, pelatihan kejuruan pada dasarnya merupakan subsistem dari sistem pendidikan.

Menurut House Committee on Education and Labor (HCEL) (Malik, 1990) : "Pendidikan kejuruan adalah suatu bentuk pengembangan bakat, pendidikan dasar keterampilan, dan kebiasaan-kebiasaan yang mengarah pada dunia kerja yang dipandang sebagai latihan keterampilan”.

Dari pengertian di atas secara garis besar bahwa salah satu ciri pendidikan kejuruan adalah berorientasi pada kesiapan peserta didik untuk memasuki lapangan pekerjaan. Konsep tersebut dapat diterapkan pula bagi anak jalanan yang sejatinya mereka kurang dalam pengetahuan dan keterampilan. Perkembangan ilmu pengetahuan dan teknologi yang semakin canggih membawa pengaruh terhadap pola kerja manusia, sehingga diperlukan bekal pengetahuan dan keterampilan yang makin tinggi. 
Maka dari itu, anak jalanan yang tidak mengenyam pendidikan formal perlu diberikan pelatihan kejuruan untuk meningkatkan keterampilan sebelum memasuki lapangan pekerjaan.

\section{Metode}

Metode yang digunakan dalam penelitian ini yaitu penelitian kualitatif deskriptif yang menggambarkan, mengungkap, dan menjelaskan fenomena yang berhubungan dengan objek penelitian. Hal ini dikarenakan dalam penelitian ini fenomena digambarkan, diungkap, dan dijelaskan apa adanya tanpa ada unsur perlakuan, manipulasi, atau pengubahan terhadap variabel-variabel yang diteliti. Jenis metode deskriptif yang diambil adalah studi kasus. Studi kasus yaitu penelitian yang dilakukan terfokus pada suatu kasus tertentu untuk diamati dan dianalisis secara cermat sampai tuntas. Lebih lanjut Arikunto (2006) mengemukakan bahwa "metode studi kasus sebagai salah satu jenis pendekatan deskriptif, adalah penelitian yang dilakukan secara intensif, terperinci dan mendalam terhadap suatu organisme (individu), lembaga atau gejala tertentu dengan daerah atau subjek yang sempit"

Penelitian ini dilakukan di Kantor Dinas Sosial Kabupaten Subang, bidang Pelayanan dan Rehabilitasi Sosial. Penelitian meliputi peran Dinas Sosial serta pembinaan anak jalanan yang ada di Kabupaten Subang. Waktu penelitian dilakukan pada akhir bulan Maret 2020 dan selesai pada Agustus 2020.

Dalam penelitian ini pengumpulan data dilakukan pada kondisi alamiah (natural setting) terhadap sumber data melalui wawancara, observasi dan studi dokumentasi.

Observasi Pengumpulan data melalui observasi dalam penelitian ini dilakukan terhadap: (1) Aktivitas perencanaan pembinaan pelatihan kejuruan bagi anak jalanan yang dilakukan oleh bagian rehabilitasi sosial. (2) Aktivitas pelaksanaan pembinaan pelatihan kejuruan bagi anak jalanan dilakukan oleh bagian rehabilitasi sosial dan anak jalanan yang dilibatkan dalam pembinaan. (3) Aktivitas evaluasi pelaksanaan pembinaan pelatihan kejuruan bagi anak jalanan dilakukan oleh bagian rehabilitasi sosial. (4) Masalah dan solusi mengenai perencanaan, pelaksanaan, dan evaluasi pembinaan pelatihan kejuruan bagi anak jalanan dilakukan oleh bagian rehabilitasi sosial dan anak jalanan yang dilibatkan dalam pembinaan.

Penulis terjun langsung di tempat yang akan di teliti, yakni Dinas Sosial, bidang Rehabilitasi Sosial kemudian penulis mengamati interaksi anak jalanan dan bagaimana peran Dinas Sosial Kabupaten Subang terhadap anak jalanan yang sekiranya dapat dilihat secara langsung sehingga penulis bisa mempunyai gambaran singkat. Kemudian dilanjutkan dengan wawancara demi mendapatkan data yang valid.

Wawancara Bentuk wawancara yang akan digunakan penulis adalah wawancara terstruktur dan wawancara tidak terstruktur. Wawancara tidak terstruktur mirip dengan percakapan informal karena pada sebagian orang lebih nyaman wawancara dengan menggunakan bahasa sehari-hari, sedangkan wawancara terstruktur menuntut pewawancara mengajukan pertanyaan-pertanyaan yang susunanya ditetapkan sebelumnya. Penulis juga akan menyamarkan identitas informan jika informan meminta. Beberapa yang dapat menjadi informan adalah anggota Dinas Sosial bagian Rehabilitasi Sosial dan anak jalanan yang diwawancara secara acak untuk mengkonfirmasi apakah benar telah dilaksanakan pelatihan kejuruan bagi anak jalanan.

Dokumentasi Studi dokumentasi dilakukan penulis untuk melengkapi data yang telah diperoleh melalui observasi dan wawancara. Studi dokumentasi ini dilakukan dengan mengambil dokumen dan data-data yang diperlukan dalam permasalahan penelitian untuk ditelaah secara intensif sehingga mendukung dan menambah kepercayaan dan pembuktian sumber data. Dokumen juga dapat dijadikan sebagai bukti bahwa wawancara dilakukan secara nyata dan tidak ada rekayasa data sedikitpun. Dalam penelitian ini dokumen yang dijadikan sumber data adalah: (1) Dokumen perencanaan pembinaan pelatihan kejuruan bagi anak jalanan. (2) Dokumen dasar hukum pelaksanaan pelatihan kejuruan bagi anak jalanan. (3) Dokumen evaluasi pembinaan pelatihan kejuruan bagi anak jalanan berupa laporan pertanggungjawaban bagian rehabilitasi sosial.

Setelah pengumpulan data, dilakukan tahap analisis data dengan menggunakan model siklus interaktif teknik analisis Miles dan Huberman Arikunto (2006) yang menyatakan bahwa "Data yang telah terkumpul melalui observasi, wawancara, dan studi dokumentasi kemudian dianalisis, selanjutnya dianalisis dengan model siklus interakatif". Untuk memperoleh tingkat kepercayaan (validasi data) dalam penelitian ini dilakukan beberapa tahap, sebagai berikut :

1. Analisis Kasus Negatif. Analisis kasus negatif dilakukan untuk menelusuri lebih lanjut data yang berbeda atau bertentangan dengan data yang ditemukan yang berasal dari beragam sumber yang ada. Analisis kasus negatif dilakukan untuk memastikan kebenaran data yang sesungguhnya. Hal ini dilakukan dengan cara melakukan obrolan ringan pada anak jalanan untuk mengkonfirmasi adanya ajakan/tawaran dari Dinas Sosial dalam program pelatihan kejuruan bagi anak jalanan di Kabupaten Subang.

2. Perpanjangan Pengamatan. Perpanjangan pengamatan dilakukan dengan cara melakukan kembali pengamatan melaui observasi, wawancara, dan studi dokumentasi terhadap data yang telah diperoleh. Perpanjangan pengamatan dilakukan dengan cara mengecek kembali kebenaran data yang telah diperoleh untuk memastikan benar tidaknya data tersebut. Perpanjangan pengamatan berhenti setelah data yang 
diperoleh betul-betul sudah jenuh atau tidak memerlukan verifikasi lagi.

\section{Hasil dan Diskusi}

Implementasi bukan hanya sekedar aktivitas, tetapi suatu kegiatan terencana untuk mencapai tujuan kegiatan. Dikaitkan dalam konteks pendidikan, implementasi kebijakan yaitu serangkaian kegiatan yang dilakukan seseorang atau sekelompok orang untuk mencapai tujuan peningkatan layanan pendidikan, dalam hal ini bentuk pelatihan kejuruan bagi anak jalanan, yang kemudian diharapkan dapat membuka lapangan kerja sendiri ditengah tantangan zaman yang semakin berkembang.

\section{Kebijakan Pelatihan Kejuruan bagi Anak Jalanan}

Kebijakan publik secara sederhana adalah konsep dasar rencana pemerintah atau organisasi publik untuk mengatur kepentingan umum atau orang banyak. Sedangkan secara umum, kebijakan publik adalah segala sesuatu yang dikerjakan dan tidak dikerjakan oleh pemerintah untuk kepentingan umum. Segala sesuatu yang dimaksud adalah setiap aturan dalam kehidupan bersama, baik itu hubungan antarwarga maupun warga dengan pemerintah. Kebijakan publik biasanya dituangkan dalam peraturan perundang-undangan seperti Undang-Undang (UU), Peraturan Presiden (PERPRES), dan Peraturan Daerah (PERDA), semua itu merupakan bentuk-bentuk kebijakan publik yang diterapkan oleh pemerintah untuk mencapai tujuan bersama. Kebijakan publik adalah suatu keputusankeputusan dari lembaga yang berwenang atau pemerintah yang menyangkut kepentingan masyarakat luas. Dalam hal ini contoh kebijakan publik adalah kebijakan pembinaan anak jalanan melalui pelatihan kejuruan.

Pada kenyataannya, pemerintah Kabupaten Subang belum mengeluarkan peraturan daerah terkait pembinaan anak jalanan, sehingga Dinas Sosial yang berperan sebagai steakholder belum dapat menjalankan pembinaan pelatihan kejuruan. Maka, pihak Dinas Sosial, bagian rehabilitasi sosial bekerjasama dengan lembaga PPSBR yang terdapat di beberapa kabupaten.

Belum terbitnya Perda mengenai anak jalanan di Kabupaten Subang tidak menutup jalan bagi Dinas Sosial untuk berinisiatif dalam penanganan anak jalanan. Maka, bentuk pelaksanaannya adalah melalui kerjasama yang dijalin langsung dengan PPSBR di berbagai kota. Bentuk kerjasama ini walaupun tidak tertulis tetap merupakan sebuah kebijakan baru dari Dinas Sosial, maka bentuk perumusan kebijakan ini senada dengan teori perumusan kebijakan institusional (kelembagaan) yang dimana proses pembuatan kebijakan fokus terletak pada struktur organisasi pemerintah. Kegiatan pembinaan tersebut berpusat pada lembaga pemerintah. Secara kelembagaan, pemerintah yang sah yang berhak membuat kebijakan. Dalam hal ini, lembaga-lembaga pemerintah yang bersifat otonom.

\section{Implementasi Pelatihan Kejuruan bagi Anak Jalanan}

Pada hakekatnya studi implementasi kebijakan adalah untuk mengetahui bagaimana kinerja suatu kebijakan publik serta mengkaji secara kritis dan evaluatif terhadap faktor-faktor yang mempengaruhi suatu kebijakan dalam mencapai tujuan kebijakan tersebut (Effendi, 2016).

Efektivitas kebijakan antara lain bisa dilihat dari proses implementasi yaitu menekankan pada konsistensi antara pelaksanaan program atau kebijakan yang merupakan petunjuk dan ketentuan pelaksanaan kebijakan yang pada hakekatnya mencakup evaluasi kinerja yang ditetapkan oleh pembuat kebijakan yang meliputi cara pelaksanaan, agen pelaksana kelompok sasaran, dan pemanfaatan kebijakan (Dwiyanto, 2006).

Dalam prakteknya, implementasi kebijakan program pembinaan anak jalanan melalui pelatihan kejuruan tetap dapat dilakukan walaupun belum terbit PERDA khusus anak jalanan, yakni bekerja sama dengan lembaga di bawah naungan Kementerian Sosial. Dalam hal ini, meminjam konsep yang dikembangkan Thomas Birkland (Akib, 2010), model implementasi kebijakan dan program ini, cenderung menerapkan model hybrid, yaitu memadukan antara regulasi yang besifat top-down, dengan kebutuhan anak jalanan dan masyarakat yang bersifat bottom up. Hal ini menggambarkan bahwa program pelayanan pelatihan itu, memiliki karakter sebagai 'jembatan antara kebutuhan masyarakat dan visi pemerintah'. Maka dari itu, program pelatihan kejuruan tidak bisa sekedar bottom-up atau top-down saja. Pelatihan kejuruan bagi anak jalanan, adalah jembatan antar aspirasi baik dari atas maupun dari bawah, dan karena itu pendekatan yang paling tepat adalah pendekatan hybrid.

\section{Masalah yang dihadapi Dinas Sosial dalam Pembinaan Anak Jalanan melalui Pelatihan Kejuruan}

Selain belum terbitnya Perda, yang menjadi masalah belum optimalnya pelatihan kejuruan dikarenakan terbatasnya sarana dan prasarana yang berasal dari keterbatasan anggaran, terdapat pula masalah secara teknis yaitu data PMKS yang tidak akurat dikarenakan kebanyakan dari anak jalanan yang terdata, bukanlah asli dari subang melainkan pendatang dari beberapa kota/kabupaten sehingga tidak memungkinkan untuk dilaksanakan pelatihan kejuruan.

Permasalahan pada pelaksanaan pelatihan kejuruan, diantaranya anak jalanan yang belum terbiasa dengan pelatihan kejuruan hingga melarikan diri, Dinas Sosial tidak melakukan pengawasan maka bisa jadi anak jalanan tersebut kembali ke dunia jalanan. Maka, pelatihan kejuruan bukanlah solusi karena apabila sebuah program 
tanpa adanya pengawasan tidak akan sampai pada tujuan yang diharapkan.

Kendala saat penawaran untuk diikutsertakan dalam pelatihan, diantaranya anak jalanan merasa sudah tidak perlu belajar karena sudah nyaman di kehidupan jalanan, kurangnya pemahaman bahwa dengan adanya pelatihan ini menjadi jalan untuk kesejahteraan keluarga anak jalanan tersebut. Dalam penyesuaiannya, pekerja sosial yang berinteraksi langsung perlu adanya strategi untuk memperbesar presentase keberhasilan dalam mengajak anak jalanan mengikuti pelatihan kejuruan. Fokus pendekatan ini adalah bukan apa yang anak jalanan lakukan, mengapa mereka melakukan, melainkan bagaimana mereka melakukan, oleh sebab itu penulis berusaha melihat bagaimana peran Dinas Sosial dalam pembinaan anak jalanan. Dinas Sosial yang dimaksudkan adalah pekerja sosial yang berperan langsung dilapangan dalam menangani anak jalanan.

\section{Upaya perbaikan yang dilakukan Dinas Sosial dalam Pembinaan Anak Jalanan melalui Pelatihan Kejuruan}

Masalah anak jalanan adalah masalah sosial bersama yang sulit terpecahkan dan menjadi problem klasik dinegara berkembang. Banyak sisi negatif terkait dengan keberadaan anak jalanan, di sisi lain anak jalanan sendiri mungkin memiliki masalah yang berat dan membuat miris. Tak jarang anak-anak dari keluarga tidak mampu sering dipaksa untuk secepatnya menjadi dewasa dengan beban tanggung jawab ekonomi keluarga secara berlebihan, sehingga mereka tidak sempat menikmati masa-masa kecilnya yang menyenangkan.

Pemerintahan Dinas Sosial selaku yang berwenang membuat kebijakan, tak hentinya memberikan solusi dengan berbagai cara dalam penanganan Penyandang Masalah Kesejahteraan Sosial (PMKS). Sehingga dalam tujuan Rencana Kerja Jangka Menengah (RKJM) Dinas Sosial Kabupaten Subang adalah "Meningkatkan Pelayanan terhadap Penyandang Masalah Kesejahteraan Sosial (PMKS), serta Perlindungan Perempuan dan Anak secara Optimal". Satu diantara PMKS yang dimaksud adalah anak jalanan. Tujuan di atas senada dengan tujuan penulis, yaitu Kebijakan dan Program Pembinaan Anak Jalanan melalui Pelatihan Kejuruan. Dalam mengemban tugas dan kewenangannya, Dinas Sosial Kabupaten Subang harus memiliki acuan langkah agar pelaksanaan tugas tetap berada pada koridor yang ditetapkan dan hasilnya dapat dirasakan secara nyata baik oleh aparatur maupun masyarakat, oleh karena itu penentuan strategi yang tepat menjadi sangat penting. Strategi untuk mencapai tujuan peran Dinas Sosial dirumuskan berdasarkan kekuatan (keunggulan), masalah dan kelemahan, serta tantangan dan peluang, baik dari lingkungan internal maupun eksternal.

1. Kelebihan Dinas Sosial dalam Pembinaan Anak Jalanan. (1) Kualitas Sumber Daya Manusia (SDM) memadai, (2) Koordinasi antar bidang sudah bagus,
(3) Komitmen pimpinan sudah baik, (4) Bekerja sama dengan Polres.

2. Peluang/Potensi Dinas Sosia dalam Pembinaan Anak Jalanan. (1) Peraturan Perundang undangan yang mendukung Tugas Pokok dan Fungsi (tupoksi) Dinas Sosial, (2) Koordinasi Mitra Sosial dan OPD berjalan Baik, (3) Adanya PSKS sebagai mitra sosial, (4) Peran serta perempuan dalam mendukung pemerintah cukup baik.

3. Tantangan Dinas Sosial dalam Pembinaan Anak Jalanan. (1) Bertambahnya jumlah anak jalanan, (2) Adanya potensi tindak kekerasan terhadap anak jalanan, (3) Belum terbitnya Perda khusus anak jalanan, (4) Jangkauan wilayah yang sangat luas.

4. Kelemahan Dinas Sosial dalam Pembinaan Anak Jalanan. (1) Kuantitas SDM belum memadai, (2) Sarana dan Prasarana kurang memadai, (3) Peranan PSKS (Potensi dan Sumber Kesejahteraan Sosial) belum maksimal, (4) Kurangnya kesadaran masyarakat, (5) Data PMKS belum akurat.

Setelah mengidentifikasi kelemahan dan kekuatan serta peluang dan tantangan, maka dalam pelaksanaannya agar tetap berada pada koridor yang ditetapkan sehingga penentuan strategi yang tepat menjadi sangat penting.

Strategi, meminjam kutipanRangkuti (2014) bahwa strategi merupakan respon secara terus menerus maupun adaptif terhadap peluang dan ancaman eksternal serta kekuatan dan kelemahan internal, maka dengan berbagai peluang dan ancaman serta kekuatan dan kelemahan yang dimiliki Dinas Sosial diperlukannya strategi untuk menangani permasalahan di atas, berikut strategi yang dilakukan Dinas Sosial Kabupaten Subang dalam penanganan anak jalanan: (1) Peningkatan pelayanan terhadap PMKS, (2) Peningkatan pelayanan perlindungan terhadap perempuan dan anak, (3) Penguatan kapasitas dan kualitas mitra sosial, (4) Peningkatan nilai-nilai kepahlawanan dan kesetiakawanan sosial, (5) Peningkatan pemberdayaa perempuan.

Strategi tidak hanya diungkapkan dan dijelaskan saja dalam bentuk dokumen, namun perlu dilaksanakan agar dijadikan sebagai arah kebijakan baru, berikut langkah strategi Dinas Sosial Kabupaten Subang: (1) Menyelenggarakan pelayanan terhadap PMKS secara merata semua wilayah, (2) Meningkatkan peran mitra sosial dalam Penanganan Penyandang Masalah Sosial (PMKS), (3) Meningkatkan pemeliharaan nilai-nilai kepahlawanan dan kesetiakawanan sosial, (4) Meningkatkan kualitas hidup perempuan dan anak, (5) Meningkatkan peran serta perempuan di bidang politik, sosial, dan ekonomi.

Kenyataannya, dilihat dari begitu banyaknya poin kelemahan di Dinas sosial menunjukkan belum optimalnya tingkat penanganan anak jalanan di Kabupaten Subang. Hal ini tampak dari berbagai kendala yang dihadapi Dinas Sosial dalam melaksanakan tahapan-tahapan kegiatan 
penanganan anak jalanan, saat pelaksanaan pelatihan pun tidak dilakukannya pengawasan sehingga menurut pengamatan dipandang belum dapat mewujudkan visi yang diinginkan.

Kendati demikian kerjasama Dinas Sosial dengan lembaga PPSBR merupakan bentuk pelayanan secara tidak langsung dalam menangani anak jalanan, walaupun secara teknis lapangan Dinas Sosial benar-benar lepas tangan saat mengantarkan anak jalanan sampai lembaga. Namun demikian kita sadari bersama bahwa permasalahan sosial tidak akan pernah terselesaikan atau hilang dari peradaban manusia. Di Indonesia permasalahan sosial menjadi tanggung jawab bersama antara pemerintah dan masyarakat, termasuk di dalamnya adalah permasalahan sosial anak jalanan. Adanya pelayanan pembinaan melalui pelatihan kejuruan bagi anak jalanan merupakan salah satu bentuk peran serta masyarakat yang didukung oleh pemerintah. Sebagai organisasi publik pemerintah perlu mengubah paradigma pelayanan publiknya agar lebih berorientasi pada kebutuhan dan kepuasan masyarakat sebagai pelanggan.

\section{Kesimpulan dan Saran}

\section{Kesimpulan}

Pembinaan pelatihan kejuruan bagi anak jalanan belum terlaksana secara optimal, selain belum terbitnya perda bupati khusus anak jalanan dan dikarenakan anggaran terbatas pula, maka Dinas Sosial khususnya bidang rehabilitasi sosial melakukan kerjasama dengan lembaga dibawah naungan Kementerian sosial yaitu lembaga PPSBR (Pusat Pelayanan Sosial Bina Remaja). Dimana lembaga ini menyediakan pelatihan kejuruan keterampilan dengan berbagai keahlian, mulai dari menjahit, bengkel, perhotelan, barber shop dan elektro. Lembaga PPSBR ini tersebar di berbagai kota/kabupaten, diantaranya Pangandaran, Cirebon, Karawang dan Lembang. Dalam perjalanannya, implementasi pembinaan melalui pelatihan kejuruan bagi anak jalanan telah terlaksana, berangkat dari kebutuhan lembaga PPSBR akan peserta pelatihan keterampilan/kejuruan, yang mana Dinas Sosial memiliki program pengurangan angka anak jalanan di Kabupaten Subang maka terbentuklah kerjasama walaupun secara tidak tertulis. Model implementasi kebijakan dan program ini, cenderung menerapkan model hybrid, yaitu memadukan antara regulasi yang besifat top-down, dengan kebutuhan anak jalanan dan masyarakat yang bersifat bottom-up. Hal ini menggambarkan bahwa program pelayanan pelatihan itu, memiliki karakter sebagai 'jembatan antara kebutuhan masyarakat dan visi pemerintah'. Maka dari itu, program pelatihan kejuruan tidak bisa sekedar bottom-up atau topdown saja. Pelatihan kejuruan bagi anak jalanan, adalah jembatan antar aspirasi baik dari atas maupun dari bawah, dan karena itu pendekatan yang paling tepat adalah pendekatan hybrid.

\section{Saran}

Berdasarkan hasil simpulan di atas, penulis mencoba memberikan beberapa hal yang ingin direkomendasikan kepada berbagai pihak yang mempunyai kepentingan untuk senantiasa peduli dengan keberadaan anak jalanan. Hal-hal yang direkomendasikan penulis sebagai berikut:

1. Pemerintah Kabupaten Subang. Sangat diharapkan Dinas Sosial yang mengadakan langsung program pelatihan kejuruan karena akan memudahkan penempatannya, dalam artian tidak perlu memindahkan anak jalanan yang sudah berminat mengikuti pelatihan kejuruan di luar Dinas Sosial karena khawatir berubah pikiran dipertengahan jalan saat menunggu diantarkan.

2. Para Pembina/Pekerjas Sosial. Semestinya adanya pengawasan ketat dari pekerja sosial baik dari lembaga PPSBR maupun Dinas Sosial terkait anak jalanan yang diantarkan, karena apabila dibiarkan maka jumlah PMKS di Kabupaten Subang tidak ada penurunan.

3. Masyarakat Kabupaten Subang. Masyarakat lebih mendukung program Dinas Sosial dengan membantu pada saat penjaringan dilakukan, tidak acuh tak acuh. Selain itu, perlunya sikap kekeluargaan pada anak jalanan karena pada dasarnya mereka membutuhkan kasih sayang.

4. Peneliti Selanjutnya. Hasil penelitian yang didapatkan, mampu dimanfaatkan sebagai pengayaan referensi oleh Peneliti lain, terutama jika akan meneliti pada fokus penelitian yang serupa. 


\section{Referensi}

Akib, Haedar. (2010). "Implementasi Kebijakan : Apa, Mengapa, dan Bagaimana". Jurmal Administrasi Publik, 1(1), 7-9.

Arikunto, Suharsimi. (2006). Metode Penelitian Kualitatif. Jakarta : Bumi Aksara.

Dwiyanto, Agus. (2006). Reformasi Birokrasi Publik di Indonesia. Edisi Kedua. Yogyakarta : Penerbit Gadjah Mada University Press.

Effendi, Leond I. (2016). "Implementasi Kebijakan Pelayanan Administrasi Terpadu". E-journal Katalogis, 4(11), 184-193

Fischer, F., Miller, Gerald J. \& Sidney, Mara S. (2007). Handbook Of Public Policy Analysis: Theory, Politics, And Methods. New York : CRC Press - Taylor \& Francis Group.
Handoyo, Eko. (2012). Kebijakan Publik, Semarang : Widya Karya Semarang - Universitas Negeri Semarang.

Karli, H., \& Margaretha, S. Y. (2002). Implementasi kurikulum berbasis kompetensi. Bandung: Bina Media Informasi.

Malik, Oemar H. (1990). Pendidikan Tenaga Kerja Nasional, Kejuruan, Kewirausahaan dan Manajemen. Bandung : PT. Citra Aditya Bhakti.

Rangkuti, Freddy.(2014). Analisis SWOT teknik Membedah Kasus Bisnis. Jakarta : Gramedia Pustaka Utama.

Undang-undang Republik Indonesia Nomor 35 Tahun 2014 Perlindungan Anak. 17 Oktober 2014. Lembaran Negara Republik Indonesia 2014 Nomor 297. Jakarta. 